\title{
Critical Comparison between the Pulsed Electric Field and Thermal Decontamination Methods of Hospital Wastewater
}

\author{
C.A. Gusbeth ${ }^{a, *}$, W. Frey ${ }^{a}$, T. Schwartz ${ }^{b}$ And A. Rieder ${ }^{b}$ \\ ${ }^{a}$ Institute for Pulsed Power and Microwave Technology, Forschungszentrum Karlsruhe \\ P.O. Box 3640, 76021 Karlsruhe, Germany \\ ${ }^{b}$ Institute for Technical Chemistry Water Technology and Geotechnology Division \\ Forschungszentrum Karlsruhe, P.O. Box 3640, 76021 Karlsruhe, Germany
}

\begin{abstract}
Filtered wastewater samples were inoculated with Enterococcus faecium and exposed to different pulsed electric field (PEF) treatment energies at 40,50 and $60^{\circ} \mathrm{C}$. A lethal effect of heat treatment on E. faecium can be observed for $T>56^{\circ} \mathrm{C}$ and a heating duration of 4 min. A treatment with $60^{\circ} \mathrm{C}, 4$ min, provokes a bacterial reduction of $4 \mathrm{log}$. A combined treatment of inoculated wastewater samples with pulsed electric field and heat $\left(40,50\right.$ and $\left.60^{\circ} \mathrm{C}\right)$ reduced the bacterial contamination considerably. At a suspension temperature of $60^{\circ} \mathrm{C}$ pulsed electric field inactivation resulted in a complete bacterial decontamination ( 8 log reduction rate). Moreover, it was demonstrated that naturally occurring nuclease activities were not changed by the pulsed electric field treatment. In contrast to a thermal treatment with temperature over $72^{\circ} \mathrm{C}$, for 4 min., the nuclease activity was reduced up to $90 \%$. In this case, inactivation is only $4 \mathrm{log}$. The same inactivation rate can be obtained by a combination of heat treatment $\left(60^{\circ} \mathrm{C}\right)$ and pulsed electric field treatment $(30 \mathrm{~J} / \mathrm{ml})$.
\end{abstract}

PACS numbers: 87.50.cj, 87.14.ej, 92.40.kc

\section{Introduction}

Several studies have shown the potential of pulsed electric fields (PEF) to decontaminate fluid foods [1]. Even if the requirements to $\mathrm{PEF}$ to provide high decontamination and uninjured products are satisfied, the energetic costs are still too high. For this reason only few producers utilize this technique and still insist on thermal treatment (pasteurisation) of liquid food products. Another promising application of PEF method is the decontamination of hospital wastewater effluents (hot-spots), which are loaded with pathogenic and increasingly antibiotic resistant bacteria. Such effluents, if not properly treated, can spread into natural environment and damage the biological balance [2]. However, in order to achieve a satisfactory bacterial inactivation $(>4 \mathrm{log})$ an electric treatment energy between $120 \mathrm{~J} / \mathrm{ml}$ and $240 \mathrm{~J} / \mathrm{ml}$ is necessary. This energy is enough to increase the fluid temperature by about $30-60 \mathrm{~K}$. Therefore, also the thermal treatment (pasteurisation) can be considered as alternative treatment. A disadvantage of the thermal treatment $\left(72^{\circ} \mathrm{C}\right)$ of hospital wastewater is the denaturation of enzymes in wastewater. These enzymes, specially the nucleases, digest the free bacterial DNA, which can transmit antibiotics persistence to other bacteria. In our study we analysed the bacterial reduction depending on temper-

\footnotetext{
* corresponding author; e-mail: christian.gusbeth@ihm.fzk.de
}

ature and the effect induced by heating on the enzyme activity present in wastewater.

\section{Materials and methods}

\subsection{Wastewater}

The wastewater was sampled at the effluent of the municipal wastewater purification plant. The conductivity of the samples ranged from 1.1 to $1.7 \mathrm{mS} / \mathrm{cm}$ at $25^{\circ} \mathrm{C}$. The wastewater properties differed according to the time of sampling. Prior to the PEF treatment, the wastewater was spiked with the target organism to reach a concentration of $10^{7}$ cells $/ \mathrm{ml}$. The treatment was performed within $4 \mathrm{~h}$ after sampling the wastewater aliquots. For the investigation of the DNA degradation activities, wastewater from a sewer of the university hospital of the city of Mainz was used.

\subsection{Microorganism}

Native wastewater samples were inoculated with the Enterococcus faecium (internal numbering, strain 2111) and exposed to different PEF treatments at 40, 50 and $60^{\circ} \mathrm{C}$. Before PEF treatment the bacteria were cultivated under shaking in growing media, kanamycin esculin azide (KAA, Merck Eurolab, Darmstadt, Germany) for $24 \mathrm{~h}$ at $37^{\circ} \mathrm{C}$ until the exponential growth phase was reached. The E. faecium cells were precipitated by centrifugation $\left(5000 \mathrm{rpm}, 5 \mathrm{~min}\right.$ at $\left.25^{\circ} \mathrm{C}\right)$. The density of the cell suspension was around $10^{7}$ cells $/ \mathrm{ml}$. 


\subsection{Determination of bacterial viability}

The viability of E. faecium after $\mathrm{PEF}$ and thermal treatment was determined by colony counting on agar plates after incubation for $48 \mathrm{~h}$. After serially diluting untreated and treated samples, aliquots of $400 \mu \mathrm{l}$ were plated on agar media: KAA for enterococci. After incubation for $48 \mathrm{~h}$ at $37^{\circ} \mathrm{C}$, the numbers of colonies forming units (CFU) on agar plates were counted. The CFU was calculated as an average of at least three plates. Only viable counts ranging from 25 to $300 \mathrm{CFU} /$ plate were considered for evaluation.

\subsection{Nuclease activity assay}

$5 \mu \mathrm{g}$ high-molecular genomic DNA of E. faecium carrying vancomycin-resistant genes were added to untreated, PEF treated or thermally treated clinical wastewater (final volume $250 \mu \mathrm{l}$ ). $20 \mu \mathrm{l}$ samples were taken at different points between 0 and $24 \mathrm{~h}$ of incubation at room temperature, immediately mixed with $2 \mu$ l loading dye, and stored at $-20^{\circ} \mathrm{C}$. The samples were analysed on a $0.7 \%$ agarose gel containing ethidium bromide.

\subsection{Simultaneous treatment with PEF and heat}

A transmission line pulse generator was used for the experiments. It delivers square pulses with a voltage amplitude between 8 and $20 \mathrm{kV}$. The pulse duration ranges from 0.1 to $10 \mu \mathrm{s}$. Commercially available electroporation cuvettes (BTX Harvardapparatus Inc., US), with a gap size of $2 \pm 0.1 \mathrm{~mm}$ and a nominal volume of $400 \mu \mathrm{l}$ were used as treatment chamber. The cuvettes and the pulse line connectors were immersed into transformer oil (Shell, Diala), which was circulated through a heat exchanger to maintain a constant temperature. The specific treatment energy was adjusted, depending on the conductivity of wastewater, by the number of pulses. The PEF treatment was applied after $90 \mathrm{~s}$ waiting time, to guarantee that the cell suspension achieved the required temperature $\left(40,50,60^{\circ} \mathrm{C}\right)$. The total exposure time to thermal treatment of the cell suspension was 4 min and $15 \mathrm{~s}$.

\section{Results and discussion}

The data in Fig. 1a show the reduction of E. faecium after treatment with PEF at different temperature as a function of the specific treatment energy in logarithmic scale. The tailing of the bacterial inactivation curve can be observed for treatments with more than $120 \mathrm{~J} / \mathrm{ml}$ (el. energy) at 20,40 and $50^{\circ} \mathrm{C}$. Simultaneous treatment of the samples, at temperature below $40^{\circ} \mathrm{C}$, did not increase the bacterial inactivation efficiency. At higher temperatures (over $40^{\circ} \mathrm{C}$ ), the bacterial reduction increased until the complete reduction (over $8 \log$ ) was achieved at $60^{\circ} \mathrm{C}$. Only thermal treatment with $60^{\circ} \mathrm{C}$ for the same duration (4 min and $15 \mathrm{~s}$ ) provokes a bacterial reduction of $4 \mathrm{log}$. The lethal treatment temperature of the E. faecium is around $56^{\circ} \mathrm{C}$. Simultaneous treatments of inoculated wastewater samples with PEF and heating (50 and $60^{\circ} \mathrm{C}$ ) reduced the bacterial contamination over the expected effect, calculated as a sum of effects induced from both treatments. This is an indication for a synergistic effect induced through the simultaneous treatment with $\mathrm{PEF}$ and heat. To reduce cost, it is conceivable to use this surplus heat energy for pre-heating the fluids before PEF treatment. In comparison, a thermal treatment with temperature over $72^{\circ} \mathrm{C}$, for $4 \mathrm{~min}$, reduces the bacterial activity up to $5 \log$ rate. This inactivation can be obtained with the simultaneous treatment with PEF $(30 \mathrm{~J} / \mathrm{ml})$ and heating up to $60^{\circ} \mathrm{C}$.

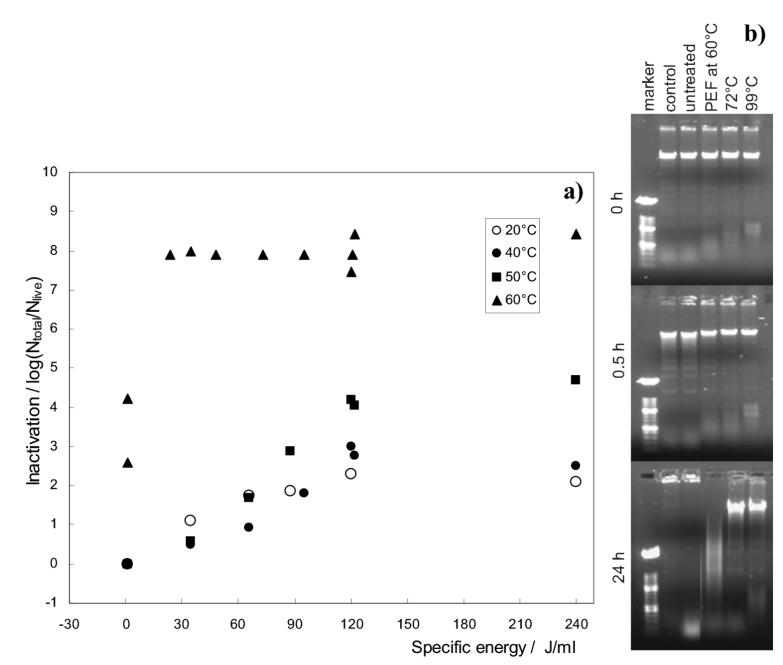

Fig. 1. (a) Inactivation efficiency of the PEF treatment of wastewater spiked with E. faecium, after treatment with PEF at different temperature as a function of the specific treatment energy in logarithmic scale. (b) Effects of thermally treated and PEF treated clinical wastewater on nuclease activities. Untreated clinical wastewater with detectable nuclease activity is used as a reference. The sample were analysed by agarose gel electrophoresis.

Untreated wastewater degraded highly molecular DNA (Fig. 1b), indicating a high nuclease activity. These enzyme activities restrict the spreading and the transfer of free DNA carrying antibiotic-resistant genes. As a control, E. faecium DNA without added wastewater was used to exclude self-degradation. No degradation was observed after $24 \mathrm{~h}$ (Fig. 1b). The clinical wastewater was subjected to PEF at treatment energy of $120 \mathrm{~J} / \mathrm{ml}$ at $60^{\circ} \mathrm{C}$ to evaluate the effects of the PEF treatment on the wastewater nuclease activities. DNA degradation became visible after $0.5 \mathrm{~h}$ of incubation and the DNA was completely fragmented after $24 \mathrm{~h}$. No differences were apparent between the nuclease activities of untreated and PEF-treated $\left(T<60^{\circ} \mathrm{C}\right)$ wastewater samples. Hence, naturally occurring nuclease activity was not significantly affected by the PEF treatment of clinical wastewater. In contrast to the PEF treatment, wastewater was treated thermally by pasteurisation or heat inactivation (i.e. $72^{\circ} \mathrm{C}$ and $99^{\circ} \mathrm{C}$, for $4 \mathrm{~min}$ ) prior to DNA 
addition. No DNA degradation could be observed after $24 \mathrm{~h}$ of incubation. The naturally occurring nuclease activity in wastewater is highly heat-sensitive and thermal treatment stops DNA degradation.

\section{Conclusions}

Our aim is to prevent the spread of antibiotic-resistant bacteria coming from hospitals wastewater. Wastewater treated with heat (up to $60^{\circ} \mathrm{C}$ ) and PEF $(120 \mathrm{~J} / \mathrm{ml})$ shows an unchanged nuclease activity and a complete bacterial inactivation. In comparison, a thermal treatment with temperature over $72^{\circ} \mathrm{C}$, for $3-4$ min, reduces the nuclease activity up to $90 \%$, at a lower inactivation rate, of $4.5 \mathrm{log}$. This bacterial inactivation can be obtained with the simultaneous treatment with PEF
$(30 \mathrm{~J} / \mathrm{ml})$ and heating up to $60^{\circ} \mathrm{C}$. Simultaneous treatment of hospital wastewater samples with PEF and heating has in comparison to pasteurization two advantages: (i) The bacterial inactivation efficiency is higher for comparable treatment energies and (ii) the nuclease activity is not affected and consequently further can digest the free DNA, which potentially carries antibiotic-resistant genes.

\section{References}

[1] A.J. Castro, G.V. Barbosa-Canovas, B.G. Swanson, J. Food Process. Pres. 17, 47 (1993).

[2] T. Schwartz, W. Kohnen, B. Jansen, U. Obst, FEMS Microbiol. Ecol. 43, 325 (2003). 